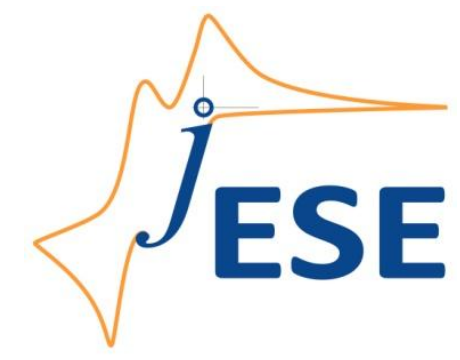

Open Access : : ISSN 1847-9286

www.jESE-online.org

Original scientific paper

\title{
Electrochemical investigations of unexplored anthraquinones and their DNA binding
}

\author{
AFZAL SHAH ${ }^{\bowtie}$, ABDUR RAUF, ASAD ULLAH, AZEEMA MUNIR, RUMANA QURESHI, \\ IFTIKHAR AHMAD, MUHAMMAD TAHIR SOOMRO, ZIA-UR-REHMAN
}

Department of Chemistry, Quaid-i-Azam University, 45320, Islamabad, Pakistan and

National Center of Excellence in Analytical Chemistry, University of Sindh, Jamshoro, Pakistan

${ }^{\square}$ Corresponding Author: E-mail: afzals qau@yahoo.com; Tel.: +925190642110; Fax: +925190642143

Received: September 15, 2012; Revised: November 2, 2012; Published: November 19, 2012

\begin{abstract}
The redox behaviour of two potential anticancer anthraquinones, 9,10-anthraquinone and 2-chloromethyl-9,10-anthraquinone was investigated in a wide $\mathrm{pH}$ range. Cyclic voltammetry based assay was developed for the assessment of the effect of medium, substituents, potential scan rate and number of scans on the voltammetric response of anthraquinones. The electrode reaction mechanism was suggested on the basis of cyclic and differential pulse voltammetric results. The effect of DNA on anthraquinones was also probed at physiological $\mathrm{pH}$ which could lead to further investigation of possible citotoxic activity in vitro. The results revealed that anthraquinones interact with DNA more strongly than the clinically used anticancer drug, epirubicin.
\end{abstract}

\section{Keywords}

Anthraquinones; redox mechanism; voltammetry; binding constant.

\section{Introduction}

Quinones are known to have a variety of biochemical and physiological functions. Literature survey reveals that these compounds are endowed with antibacterial, antifungal, antiinflammatory, wound healing, analgesic, antipyretic, antimicrobial, antibiotic and antitumor activities [1,2]. Some derivatives of quinones are common constituents of biologically important molecules such as vitamins $\mathrm{K}$ [3]. Others, like mitoxantrone and pixantrone, have been reported to have appreciable antineoplastic activity [4]. It has been reported that the biological action of quinones is due to their electron transfer rates and redox potentials [5]. Consequently, the knowledge of the redox properties of quinones derivatives seems conceivable for a better understanding of their biological action. 
Anthraquinones (AQs), an important class of tricyclic compounds, have drawn the utmost attention in medical field as anticancer drugs [6]. The main role of AQs in biological electron transport [7] and industrial processes as redox catalysts [8] have led to the extensive investigations of their electrochemical behavior $[9,10]$. Quinone-hydroquinone redox complexes are widely used in voltammetric studies due to their robust electrochemistry. The electron transfer process of most of the quinones has been reported to occur through two one-electron steps via a mechanism involving semiquinone free radical [11]. Thus, the study of electron transfer reactions is expected to provide an useful information about molecular structure [12]. Literature survey reveals that in spite of the broad range activities of quinones the electrochemical redox mechanism and DNA binding studies of biologically important AQs, 9,10-anthraquinone (AQ) and 2-chloromethyl-9,10anthraquinone (CM), is an unexplored matter at physiological $\mathrm{pH}$. To bridge this gap and to offer an explanation for the role of the selected AQs (Scheme 1) in exercising anticancer effect their detailed electrochemistry has been carried out in a wide $\mathrm{pH}$ range. Due to the existing resemblance between electrochemical and biological reactions it can be assumed that the redox mechanisms taking place at the electrode and in the body share similar principles [13]. By monitoring the variation in the electrochemical signal of the DNA binding drug it is possible to propose the mechanism of the interaction and the nature of the complex formed. Since AQs participate in several electron transfer processes in the cellular milieu, the present study is expected to provide valuable insights into molecular mechanisms of their action and designing specific DNA-targeted drugs [14].

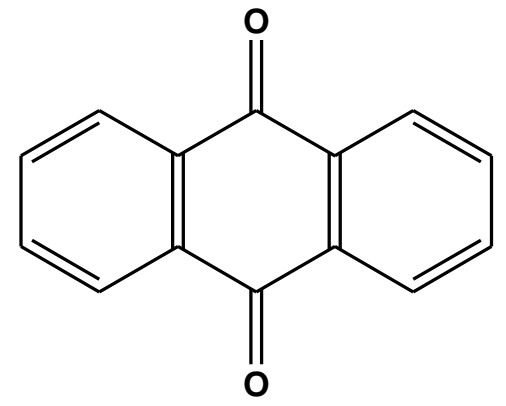

9,10-Anthraquinone (AQ)

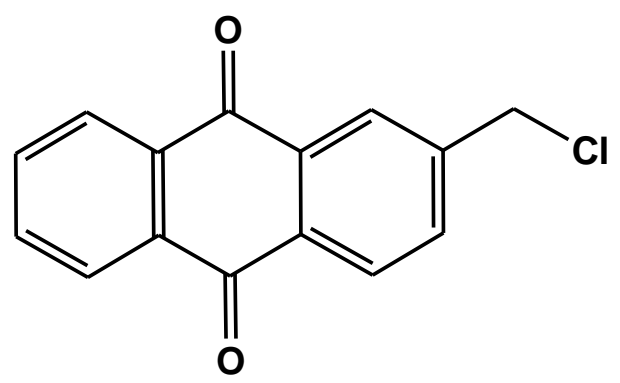

2-Chloromethylanthraquinone (CM)

Scheme 1. Structures of the chemicals used.

\section{Experimental}

Anthraquinones were purchased from Sigma and used without further purification. $0.5 \mathrm{mM}$ working solutions of AQs were prepared in $50 \%$ ethanol and $50 \%$ buffer. All supporting electrolyte solutions (Table 1 ) were prepared using analytical grade reagents. Double stranded DNA was extracted from chicken blood by Falcon method $[15,16]$. The concentration of the DNA stock solution $(2.0 \mathrm{mM})$ was determined from UV absorbance at $260 \mathrm{~nm}$ using a molar extinction coefficient $(\varepsilon)$ of $6600 \mathrm{M}^{-1} \mathrm{~cm}^{-1}[17,18]$. A ratio of absorbance at 260 and $280 \mathrm{~nm}$ of $\left(A_{260} / A_{280}\right)>$ 1.8 indicated protein free DNA [19]. Doubly distilled water was used throughout.

Voltammetric experiments were performed using $\mu$ Autolab running with GPES 4.9 software, Eco-Chemie, The Netherlands. A glassy carbon $(\mathrm{GC})\left(A=0.07 \mathrm{~cm}^{2}\right)$ was used as a working electrode, a Pt wire served as a counter electrode and a saturated $\mathrm{Ag} / \mathrm{AgCl}$ electrode was employed as the reference electrode. Before each experiment the surface of GCE was polished with alumina powder followed by thorough rinsing with distilled water. For reproducible experimental results the clean GC electrode was placed in the supporting electrolyte solution and 
various cyclic voltammograms were recorded until the achievement of a steady state baseline voltammogram. All the voltammetric experiments were conducted in a high purity argon atmosphere at room temperature $\left(25 \pm 1^{\circ} \mathrm{C}\right)$. The $\mathrm{pH}$ measurements were carried out with a Crison micro $\mathrm{pH} 2001 \mathrm{pH}$-meter with an Ingold combined glass electrode.

Table 1. Supporting electrolytes of $0.1 \mathrm{M}$ ionic strength.

\begin{tabular}{cccc}
\hline $\mathbf{p H}$ & Composition & $\mathbf{p H}$ & Composition \\
\hline 2.0 & $\mathrm{HCl}+\mathrm{KCl}$ & 7.0 & $\mathrm{NaH}_{2} \mathrm{PO}_{4}+\mathrm{Na}_{2} \mathrm{HPO}_{4}$ \\
\hline 3.0 & $\mathrm{HACO}+\mathrm{NaAcO}$ & 8.0 & $\mathrm{NaH}_{2} \mathrm{PO}_{4}+\mathrm{Na}_{2} \mathrm{HPO}_{4}$ \\
\hline 4.0 & $\mathrm{HACO}+\mathrm{NaAcO}$ & 9.0 & $\mathrm{NH}_{3}+\mathrm{NH}_{4} \mathrm{Cl}$ \\
\hline 5.0 & $\mathrm{HACO}+\mathrm{NaAcO}$ & 10.0 & $\mathrm{NH}_{3}+\mathrm{NH}_{4} \mathrm{Cl}$ \\
\hline 6.0 & $\mathrm{NaH}_{2} \mathrm{PO}_{4}+\mathrm{Na}_{2} \mathrm{HPO}_{4}$ & 12.0 & $\mathrm{NaOH}+\mathrm{KCl}$ \\
\hline
\end{tabular}

\section{Results and Discussion}

The cyclic voltammograms of $0.5 \mathrm{mM} \mathrm{AQ}$ (Fig. 1) obtained in $0.1 \mathrm{M}$ acetate based supporting electrolyte $(\mathrm{pH} 3.0)$ registered a prominent cathodic peak $1_{c}$ (more concentration sensitive) at $0.41 \mathrm{~V}$ followed by a small reduction peak $2_{\mathrm{c}}$ at $-0.60 \mathrm{~V}$. A single anodic peak $1_{\mathrm{a}}$ corresponding to oxidation of the reduction product of $A Q$ was recorded in the reverse scan. The $E_{\mathrm{p} 1 \mathrm{c}}-E_{\mathrm{p} 1 \mathrm{c} / 2}$ of $60 \mathrm{mV}$ (peak $1_{c}$ ) indicated reversible one electron transfer process as reported by the previous investigators [20]. However, the unequal anodic and cathodic peak currents pointed to the quasireversible nature of the overall electrochemical process. The decrease in the cathodic peak current of $\mathrm{AQ}$, as evident from $2^{\text {nd }}, 3^{\text {rd }}$ and $4^{\text {th }}$ voltammograms obtained under the same conditions, indicated the adsorption of the reduction product at the electrode surface.

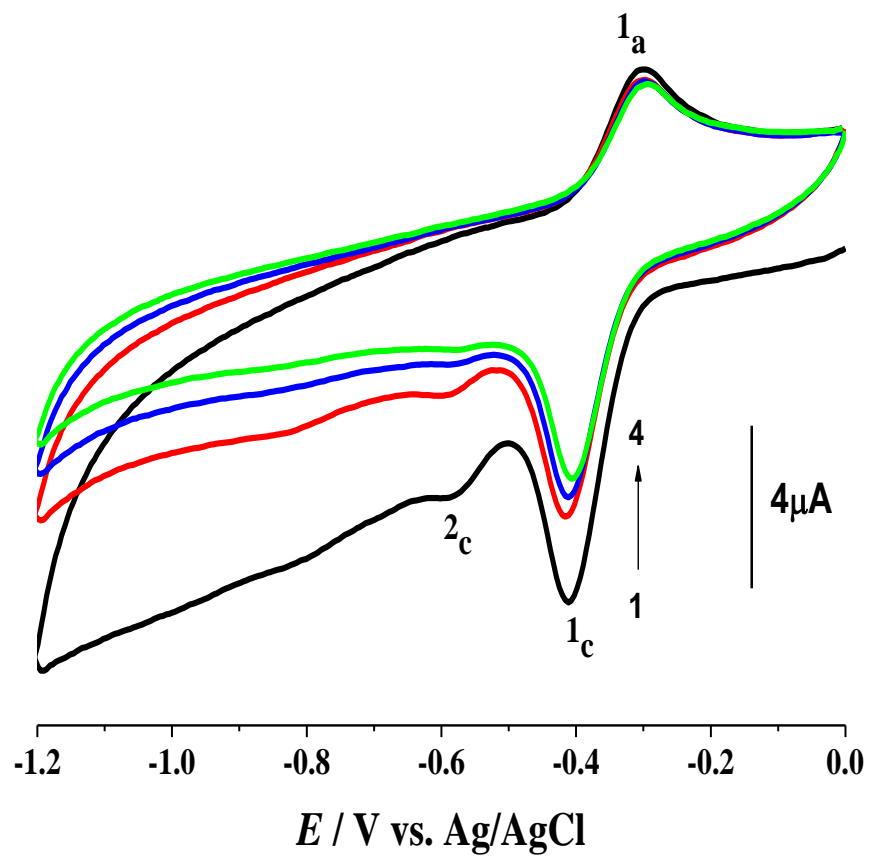

Figure 1. CVs of $0.5 \mathrm{mM} \mathrm{AQ}$ obtained in one experiment in a medium buffered at $\mathrm{pH} 3.0$ using $0.1 \mathrm{M}$ acetate based electrolyte (HAcO+NaAcO): $1^{\text {st }}, 2^{\text {nd }}, 3^{\text {rd }}$ and $4^{\text {th }}$ scans at $100 \mathrm{mV} \mathrm{s}^{-1}$.

The appearance of two cathodic peaks in the differential pulse voltammogram -DVP (shown in Fig. 2) confirmed the CV result of two step reduction of $A Q$. In non-aqueous media quinones undergo two reversible1e processes, but the results of our experiments indicate the appearance 
of one quasi reversible and another irreversible peak in a 50:50 mixture of ethanol and water. The width at the half peak height $\left(\mathrm{W}_{1 / 2}\right)$ of 91 and $93 \mathrm{mV}$ (close to the theoretical value of $90.4 \mathrm{mV}$ ) indicated the involvement of one electron in each reduction step.

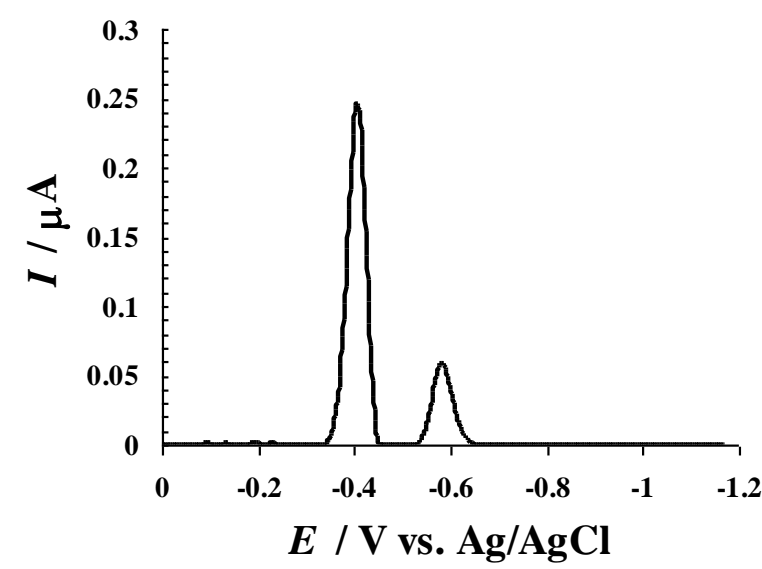

Figure 2. First scan DPV of $A Q$ obtained in $\mathrm{pH} 3.0$ at $5 \mathrm{mV} \mathrm{s}^{-1}$; pulse amplitude $=50 \mathrm{mV}$ and pulse period $=200 \mathrm{~ms}$

For the assessment of the effect of $\mathrm{pH}, \mathrm{CVs}$ of $\mathrm{AQ}$ (Fig. 3) were obtained in acidic, neutral and alkaline media. In contrast to acidic conditions, the reduction of $A Q$ at $\mathrm{pH} 7.0$ was evidenced by a sharp single cathodic peak. The appearance of two broad anodic peaks in the reverse scan showed two step oxidation of the $A Q$ reduction product The cathodic peak width $\left(E_{\mathrm{pc}}-E_{\mathrm{pc} / 2}\right)$ of $34 \mathrm{mV}$ (close to the theoretical value of $30 \mathrm{mV}$ ) indicated the transfer of two-electrons as reported by Bard et al. [20]. The equal anodic and cathodic currents at $\mathrm{pH} 9.0$, with peak potential difference of $75 \mathrm{mV}$ can be attributed to the almost reversible nature of the overall redox process under these conditions [21]. The variation in voltammetric response indicated the strong dependency of the $\mathrm{AQ}$ redox mechanism on the $\mathrm{pH}$ of the medium. With the increase in $\mathrm{pH}$, the potential of $1_{c}$ displaces to more negative values. This indicated the involvement of protons in the electroreduction of $\mathrm{AQ}$. Two peaks were also noticed in the $\mathrm{CV}$ of $\mathrm{CM}$ at $\mathrm{pH} 4.5$ (Fig. 4) but at positions different from $A Q$ indicating the modulation of the electrophore by the substituent attached at the aromatic ring. The reduction potential of $\mathrm{CM}$ was also found to shift cathodically with the increase in $\mathrm{pH}$ indicating the involvement of protons during electron transfer processes. On the basis of results obtained from CV and DPV the mechanism shown in Scheme 2 was suggested.

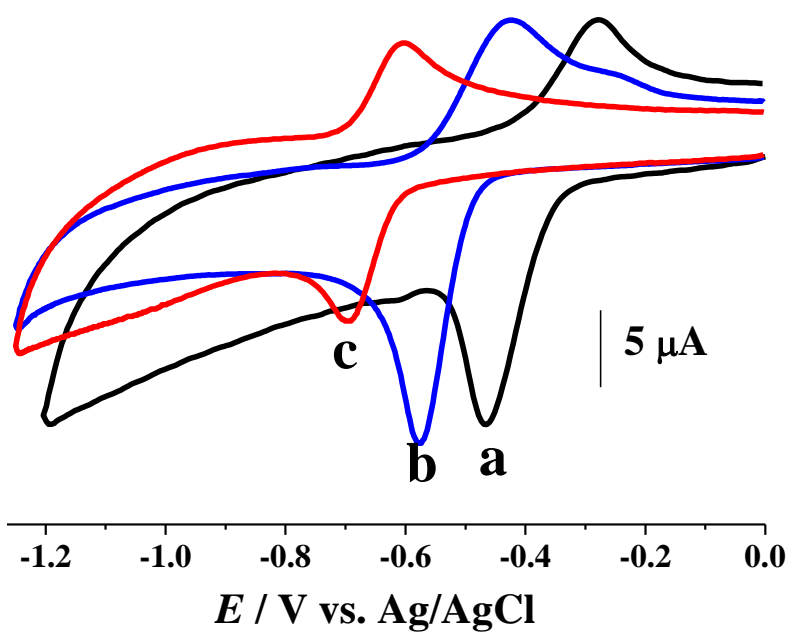

Figure 3. $1^{\text {st }}$ scan CVs of $0.5 \mathrm{mM} \mathrm{AQ}$ obtained in $\mathrm{pH}$ (a) 4.0, (b) 7.0 and (c) 9.0 at $200 \mathrm{mV} \mathrm{s}^{-1}$. 

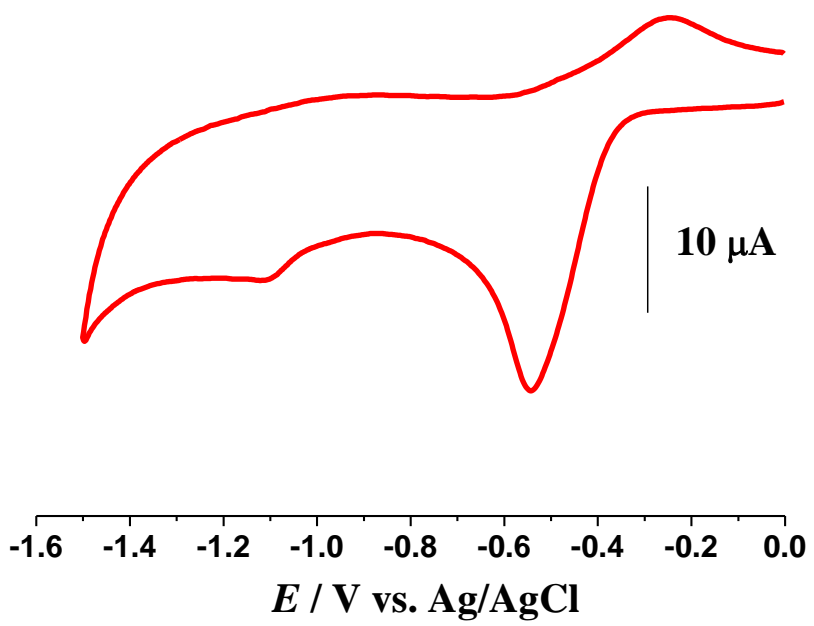

Figure 4. $1^{\text {st }}$ scan CV of $0.5 \mathrm{mM}$ CM obtained in $\mathrm{pH} 4.5$ at $200 \mathrm{mV} \mathrm{s}^{-1}$.

In order to rapidly screen the selected compounds for their anticancer activities, a relatively simple cyclic voltammetric based assay was used without performing other elaborate assays. Although easy to implement, this assay cannot be applied to electroinactive compounds in the potential window of the working electrode. In addition to it, the method is limited to compounds exerting their anticancer effect through direct interaction with DNA. In spite of these obvious limitations the assay can differentiate the binding strength and modes of action of DNA-binding compounds. As the redox behaviour of quinones is sensitive to their covalent or non covalent binding to other molecules, therefore, cyclic voltammetry was used for their DNA binding studies. For CV titrations both the concentration and volume of anthraquinones were kept constant while varying the concentration of DNA in solution. The CVs of anthraquinones in the presence of DNA have been presented at physiological $\mathrm{pH} 4.5$ ( $\mathrm{pH}$ of lysosomes of the cell) as no report is available in literature on their DNA-binding behavior under such conditions.

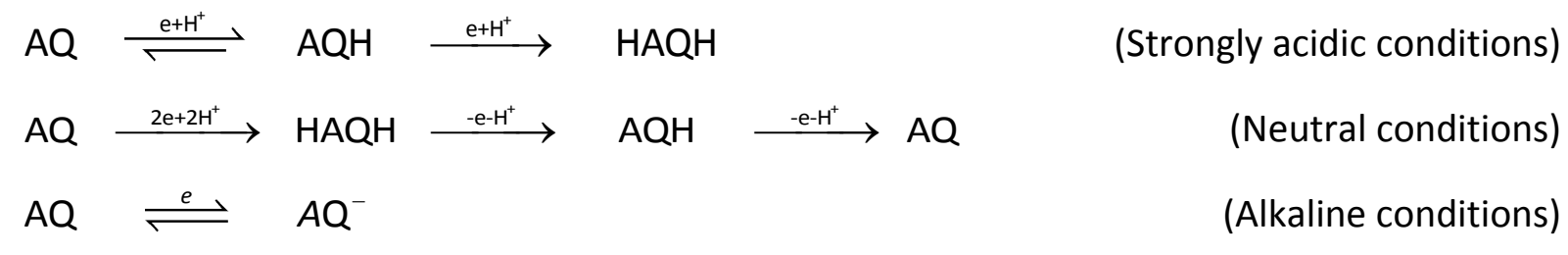

Scheme 2. Proposed redox mechanism of $A Q$

Typical CV behaviour of $0.5 \mathrm{mM} \mathrm{AQ}$ at $\mathrm{pH} 4.5$ and $v=200 \mathrm{mV} \mathrm{s}^{-1}$ in the absence and presence of 40, 100 and $120 \mathrm{nM}$ DNA has been shown in Fig. 5 . With the gradual addition of DNA, peak $1_{\mathrm{c}}$ got diminished and peak $2_{c}$ increased in height. The positive peak potential shift accompanied with the decrease in current of $1_{c}$ is attributed to the disappearance of reactant, $A Q$ and its $1 \mathrm{e}^{-}, 1 \mathrm{H}^{+}$ reduction product (HAQ) due to their intercalation into the stacked base pair domain of DNA. The increase in current of peak $2_{c}$ can be related to the greater current carrying ability of negatively charged $A^{-}$in the presence of DNA having anionic phosphate backbone.

The CV of $0.5 \mathrm{mM} \mathrm{CM}$ in the presence of $40 \mathrm{nM}$ DNA (shown in Fig. 6) showed quite different behavior from $\mathrm{AQ}$. The cathodic peak potential was shifted $(80.3 \mathrm{mV})$ anodically while the anodic peak potential underwent a drift of $30.2 \mathrm{mV}$ in the cathodic direction accompanied with the decrease in peak currents. 


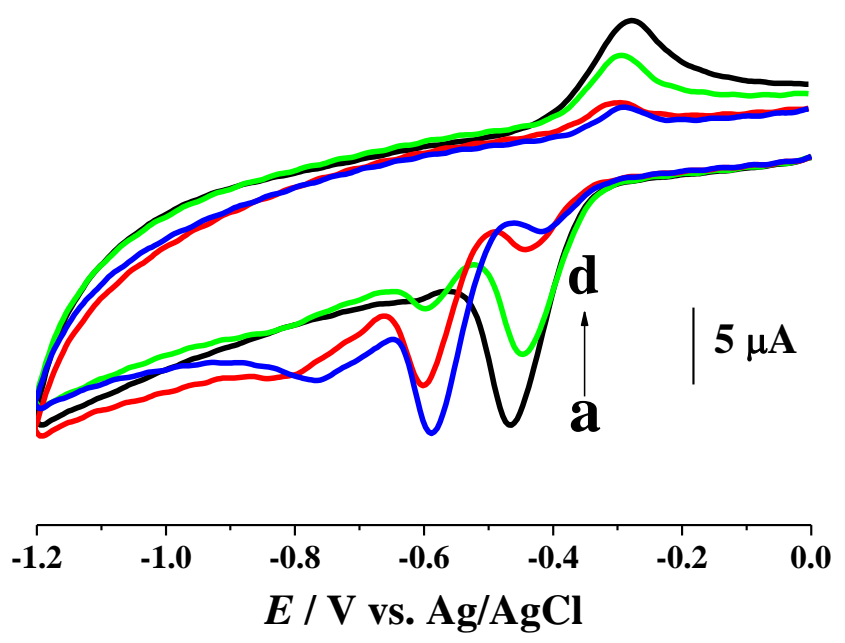

Figure 5. CVs of $0.5 \mathrm{mM} \mathrm{AQ}$ in the (a) absence and presence of (b) 40 , (c) 100 and (d) $120 \mathrm{nM}$ DNA at $\mathrm{pH} 4.5 ; \mathrm{v}=200 \mathrm{mV} \mathrm{s}^{-1}$.

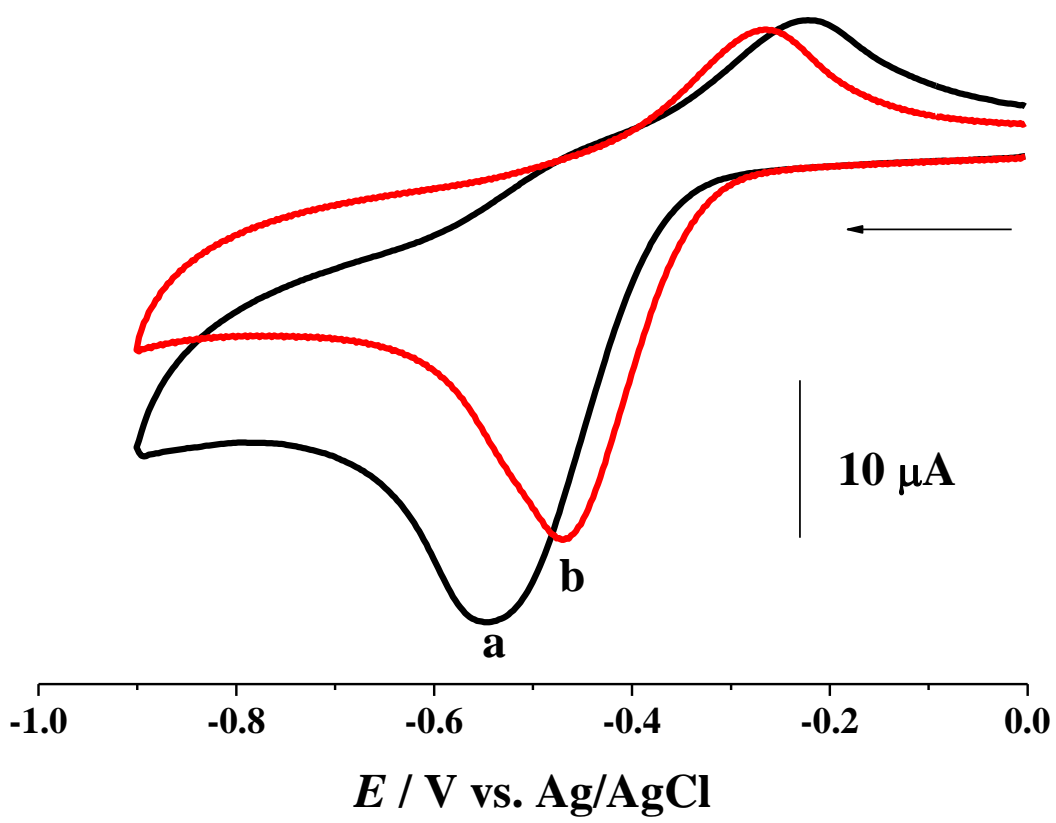

Figure 6. CVs of $0.5 \mathrm{mMCM}$ in the (a) absence and presence of (b) $40 \mathrm{nM}$ DNA at $\mathrm{pH} 4.5 ; \mathrm{v}=200 \mathrm{mV} \mathrm{s}^{-1}$.

In general the positive shift in peak potential is suggested for intercalation of the drug into the stacked base pair pockets of DNA [22], while negative shift is related to electrostatic interaction of the drug with the anionic phosphate backbone of DNA [23]. So, the obvious positive peak potential shift in the cathodic peak of $\mathrm{CM}$ can be attributed to the intercalation of $\mathrm{CM}$ into the base pair pockets of DNA. The shift in the anodic direction further indicates that $\mathrm{CM}$ is easier to reduce in the presence of DNA because its reduced form is more strongly bound to DNA than its oxidized form (neutral form). The displacement of the anodic peak in the negative going direction can be linked with the electrostatic interaction of the reduction product of $\mathrm{CM}$ with anionic oxygen of DNA. The interaction is expected to alter the DNA replication machinery that may lead to the death of cancerous cells. For such a system, where both forms of the drug interact with DNA, Scheme 3 can be applied [24]. 


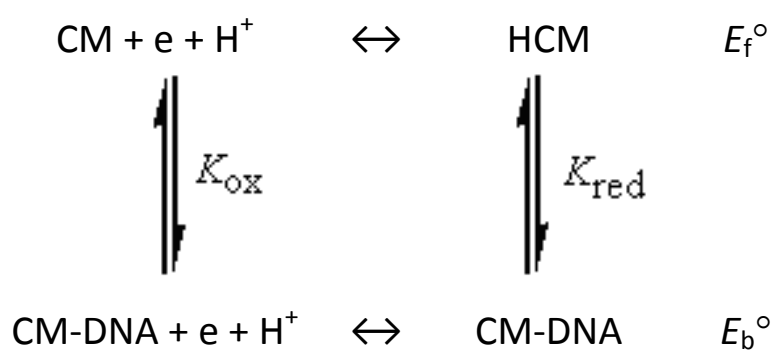

Scheme 3. General redox process of the free and DNA bound $A Q$.

Based upon the process discussed in Scheme 3, the following equation is obtained [25]

$$
E_{\mathrm{b}}{ }^{\circ}-E_{\mathrm{f}}{ }^{\circ}=0.059 \log \left(K_{\text {red }} / K_{\mathrm{ox}}\right)
$$

where $E_{\mathrm{f}}{ }^{\circ}$ and $E_{\mathrm{b}}{ }^{\circ}$ are the formal potentials of the free and DNA-bound forms of CM respectively.

For a shift of $60 \mathrm{mV}$ caused by the addition of $40 \mathrm{nM}$ DNA into $0.5 \mathrm{mM} \mathrm{CM}$ a ratio of $K_{\text {ox }} / K_{\text {red }}$ was calculated as 0.096 , which indicates 10.40 times stronger interaction of the reduced form of the drug with DNA than its oxidized form. The substantial diminution in peak current can be attributed to the formation of slowly diffusing CM-DNA supramolecular complex due to which the concentration of the free drug (mainly responsible for the transfer of current) is lowered.

The dependence of the current function $l_{p}$, on the scan rate, $v$, is an important diagnostic criterion for establishing the type of mechanism. The peak currents of these compounds were found to vary linearly with the square root of the scan rate $\left(v^{1 / 2}\right)$ as expected for diffusion-limited electrochemical process. The diffusion coefficient was determined by the following form of Randles-Sevcik equation

$$
I_{\mathrm{pc}}=-2.99 \times 10^{5} n\left(\alpha_{\mathrm{c}} n\right)^{1 / 2} A C_{\infty} D_{\mathrm{o}}^{1 / 2} v^{1 / 2}
$$

where $n$ is the number of electrons transferred during the reduction, $\alpha_{c}$ is the cathodic charge transfer coefficient, $A$ the electrode area in $\mathrm{cm}^{2}, D_{0}$ the diffusion coefficient in $\mathrm{cm}^{2} \mathrm{~s}^{-1}, C_{\infty}$ the concentration in mol cm${ }^{-3}$ and $v$ the scan rate in $\mathrm{V} \mathrm{s}^{-1}$ [26]. Taking $n=1$ (as determined from $W_{1 / 2}$ of DPV) and $\alpha_{c}=0.73$ (evaluated from $E_{\mathrm{p}}-E_{\mathrm{p} / 2}=47.7 / \alpha \mathrm{n}$ ), the values of $D$ were obtained from the plots of $I_{\mathrm{pc}} v s . v^{1 / 2}$ at $\mathrm{pH}$ 4.5. The electroactive area $\left(0.071 \mathrm{~cm}^{2}\right)$ of the working electrode was determined as described in literature [27]. From the measured slopes of $1.24 \times 10^{-5}$ and $2.17 \times 10^{-5}$ the diffusion coefficients of $A Q$ and $C M$ were determined as $2.49 \times 10^{-6}$ and $7.58 \times 10^{-6} \mathrm{~cm}^{2} \mathrm{~s}^{-1}$. The general idea about diffusivity is that the molecule having smaller molecular mass should have greater diffusion coefficient but the results of our experiments showing the opposite trend disproved the common concept. The high $D$ value of CM may be due to the presence of electronwithdrawing chlorine substituent group that will lower the electronic density at the electrophore thus increasing its affinity for reduction at the electrode surface. The lower diffusion coefficients of the DNA bound AQ $\left(9.28 \times 10^{-7}\right)$ and $\mathrm{CM}\left(1.42 \times 10^{-6} \mathrm{~cm}^{2} / \mathrm{s}\right)$ as compared to their free forms is suggestive of slowly diffusing supramolecular drug-DNA adduct formation.

Heterogeneous electron transfer rate constant $\left(k_{\mathrm{sh}}^{\circ}\right)$ was evaluated by using Nicholson equation [28] which is based on correlation between $\Delta E_{\mathrm{p}}$ and $k_{\mathrm{sh}}^{\circ}$ through a dimensionless parameter $\psi$ by following equation,

$$
\psi=\frac{\gamma k_{\mathrm{sh}}^{\circ}}{\left(\pi a D_{\mathrm{o}}\right)^{1 / 2}}
$$


where $\gamma=D_{\mathrm{o}} / D_{\mathrm{R}}, a=n F v / R T$ and $v$ is the scan rate. $\psi$ for different values of $\Delta E_{\mathrm{p}}$ can be obtained from the table reported in literature [20]. From the knowledge of $\psi, k_{\mathrm{sh}}^{\circ}$ values of $\mathrm{AQ}$ and CM were calculated as $1.02 \times 10^{-3}$ and $8.51 \times 10^{-4} \mathrm{~cm} \mathrm{~s}^{-1}$ using equation (3). The $k_{\mathrm{sh}}^{\circ}$ values also characterized the reduction processes to be quasi-reversible in nature.

Based upon the decrease in peak current of $A Q$ and $C M$ by the addition of different concentration of DNA, ranging from 20 to $120 \mathrm{nM}$, the binding constant was calculated from the intercept of the plot of $\log (1 /[\mathrm{DNA}])$ versus $\log \left(I /\left(I_{0}-I\right)\right)[29]$

$$
\log (1 /[\mathrm{DNA}])=\log K+\log \left(I /\left(I_{0}-I\right)\right)
$$

where $K$ is the binding constant, $I_{0}$ and $I$ are the peak currents of the drug in the absence and presence of DNA respectively.

The linear fitting of the amperometric data yielded the binding constant of $C M$ and $A Q$ as $2.14 \times 10^{6}$ and $1.50 \times 10^{6} \mathrm{M}^{-1}$ indicating their high affinity with DNA. The higher binding constant values than the $K=4.1 \times 10^{5} \mathrm{M}^{-1}$ of the classical intercalator, proflavin and $K=3.4 \times 10^{4} \mathrm{M}^{-1}$ of clinically used intercalating anticancer drug, epirubicin [30-32] suggested their preferred anticancer drug candidature. However, the clinical use of these drugs demands more research work on their side effects, reactions with $\mathrm{Fe}(\mathrm{III})$ in the blood and production of radicals.

\section{Conclusions}

The present study shows that anthraquinones can be reduced at the glassy carbon electrode in a $\mathrm{pH}$ dependent diffusion controlled manner involving the same number of electrons and protons. The two cathodic peaks, noticed in the $\mathrm{CV}$ of $\mathrm{CM}$ at positions different from $\mathrm{AQ}$, indicated the modulation of the electrophore by the substituent attached at the aromatic ring. The potential anticancer $\mathrm{AQ}$ and $\mathrm{CM}$ at physiological $\mathrm{pH}$ were found to interact with DNA by intercalative mode as evidenced by the decrease in current intensity and positive peak potential shift. The diffusion coefficients of free anthraquinones were found greater than their DNA-bound forms as expected. The binding constant varied in the sequence: $K_{\mathrm{CM}}>K_{\mathrm{AQ}}$ with values greater than the clinically used anticancer drugs. The investigation of the electrochemical behaviour of $A Q$ and $C M$ has the potential of providing valuable insights into biological redox reactions of this class of molecules, resulting in a better understanding of the data described for biological systems and increasing the overall knowledge of anthraquinones physiological mechanism of action.

Acknowledgements: The authors gratefully acknowledge the funds provided by Quaid-i-Azam University and Higher Education Commission Islamabad, Pakistan, for supporting this work.

\section{References}

[1] S. Dettrakul, S. Surerum, S. Rajviroongit, P. Kittakoop, J. Nat. Prod. 72 (2009) 861-865.

[2] L.S. Tien, H.L. Chi, L.L. Shih, Y.Y. Ding, Eur. J. Org. Chem. 29 (2007) 4831-4836.

[3] X. Gong, R. Gutala, A.K. Jaiswal, Vitam. Horm., 78 (2008) 85-101.

[4] B. Gatto, G. Zagotto, C. Sissi, C. Cera, E. Uriarte, G. Palù, G. Capranico, M. Palumbo,_J. Med. Chem. 39 (1996) 3114-3122.

[5] A.J. Swallow, In: Function on Quinones in Energy Conserving Systems, Academic Press; New York, 1982.

[6] S. Routier, J.L. Bernier, J.P. Catteau, J.F. Riou, C. Bailly, Anti-cancer drug des. 13 (1998) 407415.

[7] S.B. Mcloughlin, C.R. Lowe, Enzyme Microb. Tech. 20 (1997) 2-11.

[8] F. Acramone, Med. Res. Rev. 4 (1984) 153-188. 
[9] G. Dryhurst, K.M. Kadish, F. Scheller, R. Renneberg, Biological Electrochemistry, Academic Press, London, 1982.

[10] A. Salimi, K. Abdi, G.R. Khayatian, Microchim. Acta 144 (2004) 161-169.

[11] A. Bartoszek, Acta Biochim. Pol. 49 (2002) 323-331.

[12] M.E. Peover, J. Chem. Soc. (1962) 4540-4549.

[13] I. Feliciano, J. Matta, E. Melendez, J. Biol. Inorg. Chem. 14 (2009) 1109-1117.

[14] R.K. Gilpin, L.A. Pachla, Anal. Chem. 69 (1997) 145-164.

[15] N. Muhammad, A. Shah, Z. Rehman, S. Shuja, S. Ali, R. Qureshi, A. Meetsma, M.N. Tahir, J. Organomet. Chem. 694 (2009) 3431-3437.

[16] Z. Rehman, A. Shah, N. Muhammad, S. Ali, R. Qureshi, I.S. Butler, Eur. J. Med. Chem. 44 (2009) 3986-3993.

[17] A. Shah, A.M. Khan, R. Qureshi, F.L. Ansari, M.F. Nazar, S.S. Shah, Int. J. Mol. Sci. 9 (2008) 1424-1434.

[18] M.J. Han, Z.M. Duan, Q. Hao, S.Z. Zheng, K.Z. Wang, J. Phys. Chem. C., 111 (2007) 1657716585.

[19] G.D. Liu, X. Yang, Z.P. Chen, G.L. Shen, R.Q. Yu, Anal. Sci. 16 (2000) 1255-1259.

[20] A.J. Bard, L.R. Faulkner, Electrochemical Method: Fundamentals and Application J.Wiley and Sons, New York, 1980.

[21] C. Fernandez-Sanchez, T. Tzanov, G.M. Gubitz, A. Cavaco-Paulo, Bioelectrochemistry 58 (2002) 149-156.

[22] M. Aslanoglu, Anal. Sci. 22 (2006) 439-445.

[23] N. Li, Y. Ma, C. Yang, L. Guo, X. Yan, Biophys. Chem. 116 (2005) 199-205.

[24] X. Chu, G.L. Shen, J.H. Jiang, T.F. Kang, B. Xiong, R.Q. Yu, Anal. Chim. Acta 373 (1998) 29-38.

[25] T.W. Welch, H.H. Thorp, J. Phys. Chem. 100 (1996) 13829-13836.

[26] C.M.A. Brett, A.M. Oliveira Brett, Electrochemistry. Principles, methods and applications, Oxford University Press, UK, 1993.

[27] R.S. Nicholson, I. Shain, Anal. Chem. 36 (1964) 706-723.

[28] V.C. Diculescu, T.A. Enache, P.J. Oliveira, A.M. Oliveira Brett, Electroanal. 21 (2009) 10271034.

[29] A. Shah, R. Qureshi, A.M. Khan, R.A. Khera., F.L. Ansari, J. Brazil. Chem. Soc. 21 (2010) 447-451.

[30] M.T. Carter, M. Rodriguez, A.J. Bard, J. Am. Chem. Soc. 111 (1989) 8901-8911.

[31] S. Neidle, Z. Abraham, CRC Cr. Rev. Biochem. 17 (1984) 73-121.

[32] S. Charak, D.K. Jangir, G. Tyagi, R. Mehrotra, J. Mol. Struct. 1000 (2011) 150-154.

(C) 2012 by the authors; licensee IAPC, Zagreb, Croatia. This article is an open-access article distributed under the terms and conditions of the Creative Commons Attribution license (http://creativecommons.org/licenses/by/3.0/) 